Istanbul Finance Congress, November 1-2, 2018, Istanbul, Turkey.

\title{
CAUSALITY BETWEEN DOW JONES TRANSPORTATION INDEX, CPI TRANSPORTATION INDEX AND TRANSPORTATION SERVICES INDEX
}

\author{
DOI: 10.17261/Pressacademia.2018.969 \\ PAP-IFC- V.8-2018(1)-p.1-4
}

\section{Mehmet Aldonat Beyzatlar}

Dokuz Eylül University, Faculty of Business, Department of Economics, Buca, Izmir, Turkey. mehmet.beyzatlar@deu.edu.tr, ORCID:0000-0002-8434-8447

\section{To cite this document}

Beyzatlar, M. A. (2018). Causality between Dow Jones Transportation Index, CPI Transportation Index and Transportation Services Index. PressAcademia Procedia (PAP), V.8, p.1-4

Permanent link to this document: http://doi.org/10.17261/Pressacademia.2018.969

Copyright: Published by PressAcademia and limited licenced re-use rights only.

\section{ABSTRACT}

Purpose - The purpose of this study is to bridge stock index, consumer price index, and services index in transportation sector. This paper provides an empirical evaluation of causal relations between transportation measures and their financial side as a pioneering study. Methodology - This study uses monthly data for our research exercise including United States for twenty-one years, from January 2000 until June 2018. The variable of interest include Dow Jones Transportation Stock Index (DJT), Consumer Price Index: Transportation (CPIT), and Transportation Services Index (TSI).

Findings- The results indicate that the causality relations are bi-directional between all variables (i) DJT and TSI, (ii) DJT and CPIT, and (iii) TSI and CPIT.

Conclusion- In this paper, it is argued that the determination of a causal link between transportation measures and their financial side, and the nature of Granger-causality may have an important policy implication for policy makers, portfolio investors, and actors in transportation sector. The strong tendency to show bi-directional Granger-causality running between variables indicates the potentially important role of transportation in stimulating finance and vice versa.

Keywords: Transportation Services Index, Consumer Price Index, Dow Jones Transportation Index, Causality, United States, Grangercausality.

JEL Codes: C13, E31, R40, P45

\section{INTRODUCTION}

This paper aims at providing an empirical support to the causal relationship between transportation measures and financial measures in transportation sector. In contrast to the considerable literature documenting the relationship between economic measures and transportation measures, no effort has been devoted to this point to date. Therefore, the purpose of this paper is to bridge stock index, consumer price index, and services index in transportation sector. As a whole, this paper provides an empirical evaluation of causal relations between transportation measures and their financial side as a pioneering study.

The literature on the relationship between economic measures and transportation is extensive. As expected, empirical results of several studies has been showing different directions of causality relations for different country groups for different levels of aggregation and for different time dimensions. However, the existence of a causality relationship has explicitly been conferred by several studies.

An argument put forward by Beyzatlar and Yetkiner (2017) for using the transportation sector as a back-end sector of the economy is the need to income growth.

According to empirical studies revealing the causality relationship between transportation and income, the direction of causality is mainly twofold. First group of studies revealing the causality from income to transportation (Fernandes and Pacheco, 2010; Mukkala and Tervo, 2013; Hakim and Merkert, 2016). Second group of studies showing a bi-directional causality relationship (Yao, 2005; Chang and Chang, 2009; Beyzatlar et al., 2014, Pradhan and Bagchi, 2013, Baker et al, 2015; Hu et al, 2015).

In addressing the direction of causality, some empirical studies found GDP Granger-cause passenger transportation in South America using data from 1966 to 2006 (Fernandes and Pacheco, 2010) and European countries over the period 1991-2010 (Mukkala and Tervo, 2013). Hakim and Merkert (2016) revealed GDP granger-causing freight transportation in South Asia within 1973-2014.

On the other side, bi-directional causality among GDP and transportation is found by several studies see for example, Yao, 2005; Chang and Chang, 2009; Pradhan and Bagchi, 2013; Beyzatlar et al, 2014; Hu et al, 2015. 
Chang and Chang (2009) analyzed the relationship between air cargo expansion and economic growth in Taiwan for the period from 1974 to 2006. They found a long-run equilibrium by cointegration and bi-directional causality relationship between air cargo expansion and economic growth in Taiwan. Pradhan and Bagchi (2013) examined the effect of transportation infrastructure on economic growth in India over the period 1970-2010 by using Vector Error Correction Model (VECM). The authors found causality relations between transportation measures and economic growth and suggested that transportation policies are important for transportation infrastructure, which is also important for sustainable economic growth in India. Beyzatlar et al (2014) investigated the Granger-causality relations between GDP per capita and some transportation measures (freight and passenger transportation) of EU-15 countries using an annual panel data set covering the period 1970-2008. Findings of that study indicated bi-directional causality relations between income and transportation measures. Baker et al (2014) provided a significant bi-directional causality between regional aviation and economic growth by analyzing 88 regional airports in Australia over a period of 1985 to 2011 . Hu et al (2015) determined a reciprocal causality between passenger transportation and GDP based on a quarterly panel data set covering 29 provinces of China within a period 2006-2012.

Most studies, as some above, examining the role of transportation measures in most sectors and aggregate economic conditions by focusing on its influence to growth and development. However, the relationship between transportation measures and financial measures has an unignorable attraction to determine the financial role and dimension of transportation sector. By the way, it is so crucial that the determination of a causal link between transportation measures and their financial side, and the nature of Granger-causality may have an important policy implication for policy makers, portfolio investors, and actors in transportation sector. To sum up, this study has been aimed and indicated that the causality relations are bi-directional between (i) stock index and consumer price index; (ii) stock index and services index; and (iii) consumer price index and services index in transportation sector.

The remainder of the article is organized as follows. Section 2 details the data and methodology. Section 3 provides empirical findings and summarizing the results, Section 4 offers conclusions.

\section{DATA AND METHODOLOGY}

The data set for the United States covering the period from January 2000 to June 2018 has been gathered from two different sources. Dow Jones Transportation Stock Index (DJT hereafter) has been obtained from Thomson Reuters DataStream. Consumer Price Index for All Urban Consumers: Transportation, Index 1982-1984=100, Monthly, Seasonally Adjusted (CPIT hereafter) and Total Transportation Services Index, Chain-type Index 2000=100, Monthly, Seasonally Adjusted (TSI hereafter) have been obtained from Federal Reserve Bank of St. Louis. The descriptive statistics of the data are as follows in Table 1.

Table 1: Descriptive Statistics

\begin{tabular}{lllllll}
\hline & CPIT & Ln (CPIT) & DJT & Ln (DJT) & TSI & Ln (TSI) \\
\hline Mean & 186.58 & 5.22 & 5145.92 & 8.45 & 111.72 & 4.71 \\
\hline Median & 191.22 & 5.25 & 4698.77 & 8.46 & 111.60 & 4.72 \\
\hline Min & 148.70 & 5.00 & 2049.05 & 7.63 & 93.80 & 4.54 \\
\hline Max & 223.27 & 5.41 & 10972.06 & 9.30 & 134.80 & 4.91 \\
\hline Std. Dev. & 22.81 & 0.13 & 2339.76 & 0.45 & 9.11 \\
\hline Observations & 222 & 222 & 222 & 222 & 222 & 0.08 \\
\hline
\end{tabular}

The Granger-causality test, which is the most common econometric progress to detect the presence of causal relations, is used to determine the relationship between variables explained above. This test indicates the causality relationship between two variables by explaining the past values of these variables (Granger, 1969). To properly manage this process, the variables must be stationary (unit-root free) to prevent from spurious results. Therefore, unit-root tests have been applied to all variables that is also required to continue with cointegration analysis. The results of time-series unit-root tests' results of the variables are presented in Table 2. The first step in Grangercausality testing procedure is to examine whether the time series are stationary or not. Augmented Dickey Fuller (ADF), Phillips Perron (PP); Kwiatkowski Phillips Schmidt Shin (KPSS), Elliott Rothenberg Stock Point Optimal (ERSPO), and Ng Perron (NGP) have been used as the time-series unit-root testing procedures. Based on the unit root results, the second step is to test for cointegration between the variables and the last step is to analyze the Granger-causality test (Granger, 1988) in the vector autoregressive (VAR) model is specified as follows:

$\Delta \mathrm{y}_{\mathrm{t}}=\sum_{\mathrm{k}=1}^{\mathrm{p}} \alpha_{\mathrm{k}} \Delta \mathrm{y}_{\mathrm{t}-\mathrm{k}}+\sum_{\mathrm{k}=0}^{\mathrm{p}} \beta_{\mathrm{k}} \Delta \mathrm{x}_{\mathrm{t}-\mathrm{k}}+\varepsilon_{\mathrm{t}}$

$\Delta \mathrm{x}_{\mathrm{t}}=\sum_{\mathrm{k}=1}^{\mathrm{p}} \theta_{\mathrm{k}} \Delta \mathrm{x}_{\mathrm{t}-\mathrm{k}}+\sum_{\mathrm{k}=0}^{\mathrm{p}} \delta_{\mathrm{k}} \Delta \mathrm{y}_{\mathrm{t}-\mathrm{k}}+\mathrm{v}_{\mathrm{t}}$

where $\Delta$ is the difference operator, $X_{t}$ and $Y_{t}$ represent natural logarithms of the independent and dependent variables, respectively, $t$ refers to the period and $p$ to the lag, $\alpha$ 's and $\beta^{\prime}$ s are parameters to be estimated, while $\varepsilon$ and $u$ are the error terms. For Equations (1) $X$ Granger causes $Y$ and for equation (2) Y Granger causes $X$ in two ways. The estimated statistics on the coefficients of lagged values ( $\beta$ 's) are jointly statistically significant, which indicates the significance of the short-run causal effects. Toda and Yamamoto (1995) differentiated in optimal lag selection that they determined a lag length $k$, then estimated a $\left(k+d_{\text {max }}\right)$ th order VAR where $d_{\text {max }}$ is the maximal order of integration that they suspected might occur in the process.

\section{FINDINGS AND DISCUSSIONS}

The results relate to monthly time series data covering the period 2000-2018 has been used. The variables used are: DJT: Dow Jones Transportation Stock Index, to reflect the financial side of transportation sector in US; CPIT: Consumer Price Index in Transportation, to reflect price index in transportation sector; and TSI: Total Transportation Services Index, to reflect mobility in transportation sector. DJT has been gathered from Thomson Reuters DataStream, where CPIT and TSI have been obtained from Federal Reserve Bank of St. Louis. All variables are in natural logarithms. 
Table 2: Unit Root Test Results

\begin{tabular}{|c|c|c|c|c|}
\hline & & $\operatorname{Ln}(\mathrm{DJT})$ & $\operatorname{Ln}(\mathrm{CPIT})$ & $\operatorname{Ln}(\mathrm{TSI})$ \\
\hline \multirow{2}{*}{ ADF } & Level & -0.261 & -1.380 & -0.170 \\
\hline & $1^{\text {st }}$ Difference & $-5.842 * * *$ & $-10.577^{* * *}$ & $-7.722 * * *$ \\
\hline \multirow{2}{*}{ PP } & Level & -0.625 & -1.480 & 0.221 \\
\hline & $1^{\text {st }}$ Difference & $-13.640 * * *$ & $-9.419 * * *$ & $-17.766 * * *$ \\
\hline \multirow{2}{*}{ KPSS } & Level & $1.743 * * *$ & $1.636 * * *$ & $1.548 * * *$ \\
\hline & $1^{\text {st }}$ Difference & 0.048 & 0.106 & 0.176 \\
\hline \multirow{2}{*}{ ERSPO } & Level & 70.767 & 42.115 & 44.553 \\
\hline & $1^{\text {st }}$ Difference & $0.256 * * *$ & $0.167 * * *$ & $0.529 * * *$ \\
\hline \multirow{2}{*}{ NGP } & Level & 1.125 & 0.106 & 1.915 \\
\hline & $1^{\text {st }}$ Difference & $-0.732 * * *$ & $-142.272 * * *$ & $-11.662 * * *$ \\
\hline
\end{tabular}

Note: ADF: Augmented Dickey Fuller; PP: Phillips Perron; KPSS: Kwiatkowski Phillips Schmidt Shin; ERSPO: Elliott Rothenberg Stock Point Optimal; NGP: Ng Perron. ${ }^{* * *},{ }^{* *}$ and ${ }^{*}$ denotes the rejection of null hypothesis at $1 \%, 5 \%$ and $10 \%$ significance level, respectively.

Table 2 presents the results of the ADF, PP, KPSS, ERSPO and NGP tests for the levels and first differences of the natural logs of DJT, CPIT and TSI, respectively. The results show that all variables are non-stationary in levels but stationary in differences at the $1 \%$ level of significance, except KPSS, which has reverse null and alternative hypotheses with respect to other unit-root tests. Accordingly, the results suggest the variables are integrated of order one, I(1).

Table 3: VAR Lag Length Results

\begin{tabular}{lllllll}
\hline Lag & LogL & LR & FPE & AIC & SIC & HQ \\
\hline 0 & 608,6883 & NA & $6,27 \mathrm{E}-07$ & $-5,769$ & $-5,721$ & $-5,749$ \\
\hline 1 & 1535,992 & 1819,281 & $9,98 \mathrm{E}-11$ & $-14,514$ & $-14,323$ & $-14,436$ \\
\hline $\mathbf{3}$ & 1578,389 & 81,968 & $7,26 \mathrm{E}-11$ & $-14,832$ & $-14,498^{*}$ & $-14,696$ \\
\hline 4 & 1599,526 & 40,261 & $6,47 \mathrm{e}-11^{*}$ & $-14,948^{*}$ & $-14,469$ & $-14,755^{*}$ \\
\hline 5 & 1604,214 & 8,795 & $6,74 \mathrm{E}-11$ & $-14,907$ & $-14,285$ & $-14,656$ \\
\hline 6 & 1607,196 & 5,509 & $7,14 \mathrm{E}-11$ & $-14,849$ & $-14,084$ & $-14,540$ \\
\hline 7 & 1623,186 & 7,009 & $7,51 \mathrm{E}-11$ & $-14,800$ & $-13,892$ & $-14,433$ \\
\hline 8 & 1628,587 & $21,731^{*}$ & $7,29 \mathrm{E}-11$ & $-14,830$ & $-13,778$ & $-14,405$ \\
\hline 9 & 1634,593 & 9,515 & $7,55 \mathrm{E}-11$ & $-14,796$ & $-13,601$ & $-14,313$ \\
\hline 10 & 1635,836 & 10,411 & $7,78 \mathrm{E}-11$ & $-14,767$ & $-13,428$ & $-14,226$ \\
\hline 11 & 1642,561 & 2,119 & $8,40 \mathrm{E}-11$ & $-14,694$ & $-13,211$ & $-14,095$ \\
\hline 12 & 1644,635 & 11,271 & $8,60 \mathrm{E}-11$ & $-14,672$ & $-13,046$ & $-14,015$ \\
\hline
\end{tabular}

Note: LR: Likelihood Rate Test Statistics; FPE: Final Prediction-Error Criteria; AIC: Akaike Information Criteria; SIC: Schwarz Information Criteria; HQ: Hannan-Quinn Information Criteria.

Table 3 gives the results of the VAR lag selection process, which shows the optimal lag length through five different criteria. The optimal lag length is selected as three (3) for the VAR causality according to FPE, AIC and HQ criteria. Moreover, according to k=3 and dmax=1, lag length is used as four for Toda Yamamoto approach.

Table 4: Johansen Cointegration Test Results

\begin{tabular}{llllll}
\hline Data Trend: & None & None & Linear & Linear & Quadratic \\
\hline Test Type & No Intercept & Intercept & Intercept & Intercept & Intercept \\
\hline Trace & No Trend & No Trend & No Trend & Trend & Trend \\
\hline Max-Eig & 0 & 0 & 0 & 0 & 0 \\
\hline
\end{tabular}

According to the Johansen cointegration testing results as shown in Table 4, there have been no long-run relationship between DJT \& CPIT; DJT \& TSI; and CPIT \& TSI. Moreover, before testing the causality relationship, all variables have been used in natural log form and in their first differences form in order to eliminate unit roots as stated by equations (1) and (2).

Table 5: Granger-Causality Test Results

\begin{tabular}{lll}
\hline & VAR Granger Causality & Toda Yamamoto \\
\hline DJT $\rightarrow$ CPIT & Chi-sq. & Chi-sq. \\
\hline
\end{tabular}




\begin{tabular}{lll}
\hline DJT $\leftarrow$ CPIT & $12.692^{* * *}$ & $8.613^{* *}$ \\
\hline DJT $\rightarrow$ TSI & $13.257^{* * *}$ & $12.859^{* * *}$ \\
\hline DJT $\leftarrow$ TSI & $6.239^{* *}$ & $5.034^{*}$ \\
\hline & & $7.748^{* *}$ \\
\hline CPIT $\rightarrow$ TSI & $9.446^{* * *}$ & $8.249^{* *}$ \\
\hline CPIT $\leftarrow$ TSI & $9.707^{* * *}$ & \\
\hline
\end{tabular}

Note: $* * *, * *$ and $*$ denotes the rejection of null hypothesis at $1 \%, 5 \%$ and $10 \%$ significance level, respectively.

Table 5 shows short-run Granger-causality based on the vector autoregressive (VAR) and Toda Yamamoto from estimates of equations (1) and (2). The Chi-sq. statistics suggest bi-directional causality between DJT and CPIT; DJT and TSI; CPIT and TSI in the short-run by two models. The results indicated that transportation services index and consumer price index transportation are crucial for Dow Jones transportation index as financial side.

\section{CONCLUSION}

This paper looked at the causal relationship between Dow Jones transportation index, consumer price index transportation and transportation services index in US. The results of unit root tests show that all variables are integrated of the same order as I(1). The outcomes of the cointegration tests show that these variables are not cointegrated, suggesting that there is no long-run relationship between them. Furthermore, the results show a bi-directional causality between all variables. These results indicated that transportation services index and consumer price index transportation are crucial for Dow Jones transportation index as financial side, and vice versa.

\section{REFERENCES}

Baker, D., Merkert, R., and Kamruzzaman, M. (2015). Regional aviation and economic growth: cointegration and causality analysis in Australia. Journal of Transport Geography, 43, 140-150. DOI: 10.1016/j.jtrangeo.2015.02.001

Beyzatlar, M. A., Karacal, M., and Yetkiner, H. (2014) Granger-causality between transportation and GDP: A panel data approach. Transportation Research Part A: Policy and Practice, 63, 43-55. DOI: 10.1016/j.tra.2014.03.001

Beyzatlar, M. A., and Yetkiner, H. (2017). Convergence in transportation measures across the EU-15. Transportation, 44(5), 927-940. DOI: 10.1007/s11116-016-9686-6

Chang, Y. H. and Chang, Y. W. (2009). Air cargo expansion and economic growth: Finding the empirical link. Journal of Air Transport Management, 15(5), 264-265. DOI: 10.1016/j.jairtraman.2008.09.016

Fernandes, E. and Pacheco, R. R. (2010). The Causal Relationship between GDP and Domestic Air Passenger Traffic in Brazil. Transportation Planning and Technology, 33(7), 569-581. DOI: 10.1080/03081060.2010.512217

Granger, C. W. (1969). Investigating Causal Relations by Econometric Models and Cross-Spectral Methods. Econometrica, 37(3), 424-438.

Granger, C. W. (1988). Some recent development in a concept of causality. Journal of econometrics, 39(1-2), $199-211$.

Hakim, M. M., and Merkert, R. (2016) The causal relationship between air transport and economic growth: Empirical evidence from South Asia. Journal of Transport Geography, 56, 120-127. DOI: 10.1016/j.jtrangeo.2016.09.006

Hu, Y., Xiao, J., Deng, Y., Xiao, Y., and Wang, S. (2015) Domestic air passenger traffic and economic growth in China: Evidence from heterogeneous panel models. Journal of Air Transport Management, 42, 95-100. DOI: 10.1016/j.jairtraman.2014.09.003

Mukkala, K., and Tervo, H. (2013). Air transportation and regional growth: which way does the causality run? Environment and Planning A, 45(6), 1508-1520. DOI: 10.1068/a45298

Pradhan, R. P., and Bagchi, T. P. (2013) Effect of transportation infrastructure on economic growth in India: the VECM approach. Research in Transportation Economics, 38(1), 139-148. DOI: 10.1016/j.retrec.2012.05.008

Toda, H. Y., and Yamamoto, T. (1995). Statistical inference in vector autoregressions with possibly integrated processes. Journal of econometrics, 66(1-2), 225-250.

Yao, V. W. (2005). The causal linkages between freight and economic fluctuations. International Journal of Transport Economics/Rivista internazionale di economia dei trasporti, 143-159. 